\title{
Approval of Take-out Mergers by Minority Shareholders: From Substantive to Procedural Fairness
}

Modern state corporation laws permit a majority shareholder to expel minority shareholders by forcing them to accept an unnegotiated price for their shares. ${ }^{1}$ Dissident minority shareholders can seek injunctive relief, rescission, damages, or a statutory appraisal. ${ }^{2}$ Courts, however, have been

1. E.g., Cal. Corp. Code $\S 1001$ (West 1977 \& Supp. 1984); Del. Code ANN. tit. 8, $\$ \S 251$, 253 (1983); N.Y. Bus. Corp. LAW $\S 902$ (McKinney 1963 \& Supp. 1983-1984); Model Bus. CORP. ACr $\S 71$ (1979). The evolution of state merger statutes is traced by Balotti, The Elimination of the Minority Interests by Mergers Pursuant to Section 251 of the General Corporation Law of Delau'are, 1 DEL. J. CoRp. L. 63 (1976); Carney, Fundamental Corporate Changes, Minority Shareholders, and Business Purposes, 1980 AM. B. Found. Research J. 69; Weiss, The Law of Take Out Mergers: A Historical Perspective, 56 N.Y.U. L. Rev. 624 (1981) [hereinafter cited as Weiss, Historical Perspective]; Weiss, The Law of Take Out Mergers: Weinberger v. UOP, Inc. Ushers in Phase Six, 4 Cardozo L. Rev. 254 (1983) [hereinafter cited as Weiss, Phase Six].

2. Because mergers are quickly executed and difficult to undo, preliminary injunctions and rescissions are rarely granted. See Weinberger v. UOP, Inc., 457 A.2d 701, 714 (Del. 1983) ("this long completed transaction is too involved to undo"); Klein v. Soundesign Corp., Nos. 6636, 6643 (Del. Ch. Jan. 21, 1982), reprinted in 7 Del. J. Corp. L. 332, 336 (1982) ("A preliminary injunction will not issue unless a plaintiff has established a reasonable probability of ultimate success on final hearing ... ."); Lynch v. Vickers Energy Corp., 429 A.2d 497, 501 (Del. 1981) ("Rescission is the preferable remedy . . . [ [but] is not feasible at this late date. TransOcean has been merged into Esmark and time has brought other corporate changes."). Whatever the initial form of the complaint, the plaintiff's usual objective is rescissory damages, a remedy that requires defendant to pay plaintiff a pro rata share of the gains actually realized from the merger as of the date judgment is entered. See id. The Delaware appraisal remedy, as liberally construed by the court in Weinberger, permits rescissory damages, despite the statutory language excluding "any element of value arising from the accomplishment or expectation of the merger," DEL. CoDE ANN. tit. 8, $\$ 262(\mathrm{~h})(1983)$, provided that the gains are not speculative. 457 A.2d at 714 (appraisal may include "elements of rescissory damages if the Chancellor considers them susceptible of proof and a remedy appropriate to all the issues of fairness before him"). In cases where the appraisal remedy does not by its terms apply (e.g., a tender offer or a sale of assets, instead of a merger) or limits recovery (e.g., to pre-merger values), courts are increasingly willing to expand it in the exercise of their equitable discretion. See Lynch v. Vickers Energy Corp., 402 A.2d 5 (Del. Ch. 1979):

[A] though the Delaware Corporation Law makes no statutory provision for . . damages arising as a consequence of an alleged unfair offer of a parent corporation to buy the stock of its subsidiary's minority stockholders for an inadequate consideration ... I conclude that a proceeding analogous to an appraisal hearing such as is provided for in merger cases is appropriate here.

Id. at 11. In Delaware, suits for breach of fiduciary duty are now subsumed by the appraisal hearing and analogous judicial proceedings. See Weinberger v. UOP, Inc., 457 A.2d at 714 (in cases where appraisal is not adequate, "the Chancellor's powers are complete to fashion any form of equitable and monetary relief as may be appropriate, including rescissory damages"). Criticism of appraisal as a limited or mechanical remedy is thus no longer warranted. For examples of such criticism applied to the pre-Weinberger appraisal remedy, see Brudney \& Chirelstein, Fair Shares in Corporate Mergers and Takeoters, 88 Harv. L. Rr.v. 297, 304-07 (1974); Manning, The Shareholder's Appraisal Remedy: An Essay for Frank Coker, 72 YALE L.J. 223 (1962); Vorenberg, Exclusiveness of the Dissenting Slockholder's Appraisal Right, 77 HaRv. L. REv. 1189 (1964). 
unable to devise uniform methods of calculating a share's intrinsic value. ${ }^{3}$ Thus their opinions regarding the substantive fairness of take-out mergers lack sufficient precedential force to guide corporate planning or to permit dismissal of groundless suits before trial. ${ }^{4}$ No refinement of economic analysis can solve this problem because even if a take-out were demonstrably fair in some objective sense, it would still raise questions of fairness when imposed on the minority against its will. ${ }^{5}$ Courts should abandon the effort to establish objective economic criteria of substantive fairness in favor of the more modest but more workable goal of procedural fairness: to safeguard free choice. Procedural fairness grounded in informed decisionmaking provides a basis for adjudication more in keeping with the policies of state merger statutes, the disclosure requirements of federal securities regulation, and judicial competence.

This Note argues that a take-out merger is procedurally fair if it requires an informed affirmative vote by a majority of the minority shares.

3. "Intrinsic value," the underlying objective worth of a share, is the measure of a substantially fair price. For the elements of intrinsic value, see Tri-Continental Corp. v. Battye, 31 Del. Ch. 523, 74 A.2d 71, 72 (1950). For an indication of the complexity of "intrinsic value," see Weinberger v. UOP, Inc., 426 A.2d 1333, 1356-62 (Del. Ch. 1981) (comparative analysis and discounted cash flow as competing methods of valuation), rev'd 457 A.2d 701, 712 (Del. 1983) (rejecting as outmoded the "Delaware block" or weighted average method of computing share value).

4. See generally" Fischel, The "Race to the Bottom" Rerisited: Reflections on Recent Developments in Delau'are's Corporation Law, 76 Nw. U.L. Rev. 913, 942 (1983) (Singer cases are departure from prior case law); Weiss, Phase Six, supra note 1, at 258 (court, on its own volition, undertook to review and overrule the Singer cases). Given the remarkable instability of judicial precedents in this area, neither shareholders nor corporate managers can be certain of their rights and liabilities in planning, contesting, or defending take-out mergers.

5. The unfairness of coercive take-outs is urged by Cary, Federalism and Corporate Law: Reflections Upon Delaware, 83 Yale L.J. 663 (1974), and Brudney \& Chirelstein, supra note 2, at 297. These authorities may have persuaded the Delaware court, in Singer v. Magnavox, 380 A.2d 969 (Del. 1977), to reject the position earlier taken in David J. Greene \& Co. v. Schenley Indus., 281 A.2d 30 (Del. Ch. 1971):

[U]nder the law of merger each minority stockholder . . . has had at least constructive notice that he may be lawfully eliminated as such a stockholder unless the plan of corporate reorganization designed to absorb his stock interest is so grossly unfair as to be invalid . . . [I]f plaintiffs and others are not satisfied with the value placed on their shares by [defendant], and no fraud or blatant overreaching is demonstrated, their recourse is to an appraisal.

Id. at 35. Accord Stauffer v. Standard Brands, Inc., 187 A.2d 78, 80 (Del. 1962); Federal United Corp. v. Havender, 24 Del. Ch. 318, 11 A.2d 331, 342 (1940). In Weinberger v. UOP, Inc., 457 A.2d 701,715 (Del. 1983), the court announced its "return to the well established principles" of these cases "mandating a stockholder's recourse to the basic remedy of an appraisal." See supra note 2. It is not possible to determine in the abstract whether the forced removal of minority shareholders is inherently unfair, regardless of the price. Take-out mergers present conflicting equities that cannot be credibly or consistently resolved by any substantive theory or principle. Hence this Note argues that the emphasis of adjudication should shift from substantive to procedural fairness.

6. Several courts and commentators have considered minority approval, but they treat it as a variant of ex post shareholder ratification of voidable corporate actions. This analysis overlooks the importance of the minority's vote as a substitute for the otherwise coercive imposition of majority will and instead seeks objective measures of fair price as the primary criteria of substantive fairness. Thus, no court or commentator reaches the conclusion urged in this Note: that procedural fairness achieved through minority approval is a better standard of equity than reliance on objective economic criteria of intrinsic value and substantive fairness. The legal effect of minority approval was an issue "of first 
This Note argues further that both shareholders and courts should prefer disclosure and free choice as better guides to an equitable result than objective indicators of intrinsic value. Minority approval of parent-subsidiary mergers and "going-private" transactions invites courts to bring to substantive state corporation law the rationale of disclosure underlying federal securities regulations. The Note concludes with an analysis of the benefits gained by all parties when take-out mergers are effected by minority approval.

\section{State and Federal Law of Take-out Mergers}

State and federal courts approach take-out mergers from opposite directions. State courts, applying substantive state corporation law, judge the substance of a transaction-in particular, its price-against objective measures of intrinsic value. In contrast, federal courts, applying federal securities regulations, leave substantive issues to state courts and limit their inquiry to the central procedural issue of disclosure. Both perspectives are deficient. The substantive issues are too difficult for courts to resolve consistently; the question of sufficient disclosure lacks substance in take-out mergers, where the minority shareholders, certain to be outvoted, have no meaningful choice to make.

\section{A. State Law}

State courts assessing take-out mergers give primary consideration to price." Although the Delaware Supreme Court divides the question of

impression" for the Delaware courts in 1979. Weinberger v. UOP, Inc, 409 A.2d 1262, 1264 (Del. Ch. 1979). Minority approval was mentioned by Borden, Going Private - Old Tort, New Tort, or No Tort?, 49 N.Y.U. L. REv. 987, 1039 (1974) (minority approval makes the equities of going private transactions "much clearer"), but disapproved by Brudney \& Chirelstein, supra note 2, at 300, 333 ("[T]he process of seeking stockholder approval is skewed in favor of a vote for approval . . . . [Minority] stockholders will accept a pittance which bears no relationship to any freely bargained division of the premium."). The most extensive treatment occurs in an essay by Chazen, Fairness from a Financial Point of View in Acquisitions of Public Companies: Is "Third-Party Sale Value" the Appropriale Standard?, 36 Bus. LAw. 1439, 1474-77 (1981) (minority shareholders will vote for a second-best price lower than would be gained for them by an independent negotiator); see also Weiss, Historical Perspective, supra note 1, at 676-77 (only courts can determine the fairness of a merger price because shareholders routinely follow management's recommendations, accept second best alternatives, and have fiduciary rights not subject to vote).

7. Courts have ruled that take-out mergers must have a valid business purpose as well as provide stockholders a fair price. Tanzer v. International Gen. Indus., Inc., 379 A.2d 1121, 1122-25 (Del. 1977); Singer v. Magnavox, 380 A.2d 969, 978-80 (Del. 1977). But courts are ill-equipped to secondguess business judgments and generally excuse themselves from doing so by invoking the "business judgment rule," according to which decisions within the scope of management's discretion are presumed to be valid. See Gilson, A Structural Approach to Corporations: The Case Against Defensive Tactics in Tender Offers, 33 STAN. L. REv. 819, 822-24 (1981) (market better able to police errors in business judgment than courts). The Delaware court has recently discarded the business purpose test on the ground that it has been "virtually interpreted out of existence." Weinberger v. UOP, Inc., 457 A.2d 701, 715 (Del. 1983) (quoting Weiss, Historical Perspective, supra note 1, at 671 n.300). 
fairness into a substantive aspect, "fair price," and a procedural aspect, "fair dealing," the former is more important than the latter, save in cases of outright fraud. ${ }^{8}$ Unfair dealing includes fraud, overreaching, hurried transactions that deny directors an opportunity for careful deliberation, lack of arm's-length negotiation with representatives of the minority shareholders, and nondisclosure of the value the acquirer hopes to gain from the transaction. ${ }^{9}$ Unfair dealing is important insofar as it results in, or conceals, an unfair price.

In determining whether a disputed price is fair, the Delaware Supreme Court is willing to consider "any techniques or methods which are generally considered acceptable in the financial community and otherwise admissible in court."10 But the elements of fair price, such as market value, liquidation value, third-party sale value, benefits from synergy, and the relative weight to be assigned to each, cannot be established by courts in a consistent and predictable manner that will offer effective guidance to future corporate behavior. ${ }^{11}$ Different methods of valuation "generally considered acceptable," such as comparative analysis and discounted cash flow analysis, frequently produce contradictory indications of the "fair" price. $^{12}$

Even if an objectively fair price could be determined, the consequences of a take-out merger at that price would not be uniformly fair to each

Unfortunately, neither the court nor the commentators on whom it relied considered that a judicially imposed obligation to demonstrate a valid business purpose could have been employed to require corporate planners carefully to consider all alternative means of accomplishing their objective. While it is unlikely that a corporation large enough to have publicly traded shares would undertake a major reorganization merely as a subterfuge for eliminating the minority (for motives other than the permissible business purpose of reducing costs), it might opt for a take-out because it seemed the quickest and most obvious route, even though some other means might have been contrived to achieve the same objectives. On the application of the business judgment rule by federal appellate courts, see Comment, The Misapplication of the Business Judgment Rule in Contests for Corporate Control, 76 Nw. U.L. REv. 980 (1982):

The courts have allowed the broad mantle of business judgment to obscure the inadequacy of directorial investigation into all of the implications involved in pending control contests .... [Shareholders'] interests can be protected only by increasing the level of judicial inquiry into incumbent directors' performance of their duties, and by shifting the burden of proof to the directors to show that implemented defensive tactics [against takeovers] are motivated by a compelling corporate interest.

Id. at 1013-14.

8. Weinberger v. UOP, Inc., 457 A.2d 701, 711 (Del. 1983) ("in a non-fraudulent transaction . . price may be the preponderant consideration outweighing other features of the merger").

9. Id. at $711-12$.

10. Id. at 713 .

11. See Nathan \& Shapiro, Legal Standards of Fairness of Merger Terns Under Delauare Lau, 2 DEL. J. CoRP. L. 44, 50-64 (1977) (substantive fairness measured by market value, earnings value, net asset value, comparative per share analysis, and valuation of debt, preferred stock, and convertible securities); supra note 3.

12. See Weinberger v. UOP, Inc., 426 A.2d 1333, 1356-62 (Del. Ch. 1981) rev'd on other grounds 457 A.2d 701 (Del. 1983) (examination of expert testimony; conflicting assessments of intrinsic value ranging from $\$ 14$ to $\$ 32$ per share). 
minority shareholder, unless all of them had the same level of risk aversion, the same assessment of the company's prospects, the same basis in its stock, and the same portfolio of investments. ${ }^{13}$ Experts disagree over the variance in shareholder expectations, the propriety of including losses resulting from adverse tax consequences or lack of portfolio diversification, and the need to recognize other individual circumstances in assessing fairness. ${ }^{14}$

Similar uncertainty surrounds any increases in value resulting from the merger. The anticipated gains cannot be measured exactly; the variables are too numerous and their interactions too complex..$^{15}$ Even if the facts were undisputed, there is no agreement as to what principle the court should apply in determining a fair distribution of the merger gains. ${ }^{16}$ Some have urged that minority shareholders, contributing nothing to the merger except potential obstacles to its completion, are free-riders who deserve none of the gains, ${ }^{17}$ while others insist that they should receive the "reservation price," which is the maximum the acquirer is willing to pay. ${ }^{18}$ Given this lack of consensus, there is little likelihood that courts will be able to reach consistent and reliable determinations of substantive fairness.

Even if a merger price were shown to be objectively and uniformly fair, it would not follow that it could be fairly imposed on the minority against

13. Singer v. Magnavox, 380 A.2d 969, 977 n.8 (Del. 1977); Toms, Compensating Shareholders Frozen Oul in Two-Slep Mergers, 78 Colum. L. Rev. 548, 556 n.23 (1978).

14. Sep Toms, supra note 13. Compare Fischel, supra note 4, at 925 n.69 ("If one shareholder valued shares at a higher price than the market price, this shareholder would long ago have purchased the shares held by other shareholders. By this process of arbitrage, different values for the same asset-the shares-would have been eliminated and an equilibrium price would be reached.") with Brudney, Equal Treatment of Shareholders in Corporate Distributions and Reorganizations, $71 \mathrm{CA}^{-}$ LIF. L. REv. 1072, 1076 n.10 (1983) ("The 'value' of an aliquot portion of the enterprise represented by a share of its common stock may be said to depend not only upon the value of the enterprise, but also upon the personal tax positions, portfolios, or other economic requirements of the individual investors involved.").

15. Tanzer v. International Gen. Indus., 402 A.2d 382, 393-95 (Del. Ch. 1979) (gains usually impossible to ascertain, not shown to be in excess of premium offered to minority shareholders, and excluded from consideration by state appraisal statute). But see Weinberger v. UOP, Inc., 457 A.2d 701,713 (Del. 1983) ("But elements of future value . . . which are known or susceptible of proof as of the date of the merger and not the product of speculation, may be considered."); Brudney, supra note 14, $1104 \mathrm{n} .93$ ("Weinberger, in 'liberalizing' the relief available under the appraisal remedy, implies some sort of sharing, but leaves the matter frightfully opaque.").

16. Sep Bebchuk, The Case for Facilitating Competing Tender Offers: A Reply and Extension, 35 STaN. L. Rev. 23 (1982); Brudney \& Chirelstein, supra note 2; Easterbrook \& Fischel, Auctions and Sunk Cosls in Tender Offers, 35 STAN. L. REv. 1 (1982); Gilson, Seeking Competitize Bids Versus Pure Passizily in Tender Offer Defense, 35 Stan. L. Rev. 51 (1982); Lorne, A Reappraisal of Fair Shares in Cointrolled Mergers, 126 U. PA. L. REv. 955 (1978).

17. Grossman \& Hart, Takeoter Bids, the Free-Rider Problem, and the Theory of the Corporation, 11 Bel. J. Econ. \& MGMT. Sci. 42, 43 (1980).

18. Weiss, Phase Six, supra note 1, at 253 ("minimum measure of fair value in a take out merger is the highest price that the controlling stockholder is prepared to pay to obtain complete ownership of its subsidiary"). 
its will. ${ }^{19}$ Even though investors hold their shares subject to state corporation laws and corporate charters permitting take-out mergers, courts have not always ruled in favor of controlling shareholders. Instead, by employing the doctrine that the majority owes a fiduciary obligation to the minority, ${ }^{20}$ courts have severely qualified the majority's statutory power to cash-out the minority. The conflict between statutory power and equitable obligation is further complicated by the tension between the controlling shareholder's duty to the minority shareholders and its duties to the corporation it controls and its minority shareholders (if any), for whom the merger may represent a valuable corporate opportunity. ${ }^{21}$ Standing on both sides of the transaction, the controlling shareholder faces conflicting obligations. ${ }^{22}$ This impasse can be resolved only by procedures that enable the minority to protect its own interests, thereby reducing the controlling shareholder's power in order to release it from responsibilities it cannot fulfill.

19. Sep Tanzer, 402 A.2d at 391 ("To force a stockholder to accept an investment which he does not want may be just as unfair as it is to force him to divest himself of an investment he is happy with by requiring him to turn in his shares in a cash-out merger."). The controlling shareholder's power under state merger statutes to cash out the minority is often likened to the power of eminent domain, but the analogy is inconsistent with the concept of fiduciary duty. For the eminent domain analogy, see Singer v. Magnavox Co., 380 A.2d 969, 978 (Del. 1977); Federal United Corp. v. Havender, 24 Del. Ch. 318, 11 A.2d 331 (1940); Carney, supra note 1, at 70 n.5.

20. Weinberger v. UOP, Inc., 457 A.2d 701, 710 (Del. 1983) ("The requirement of fairness is unflinching in its demand that where one stands on both sides of a transaction, he has the burden of establishing its entire fairness, sufficient to pass the test of careful scrutiny by the courts."); Singer v. Magnavox, 380 A.2d at 976 ("the dominant corporation, as a majority stockholder standing on both sides of a merger transaction, transaction has 'the burden of establishing its entire fairness' to the minority stockholders, sufficiently to 'pass the test of careful scrutiny by the courts" "). Despite Weinberger's express adherence to the Singer requirement that the defendant has "the burden of establishing . . . [the take-out's] entire fairness," two commentators have interpreted Weinberger as a repudiation of Singer. Berger \& Allingham, A New Light on Cash-Out Mergers: Weinberger Eclipses Singer, 39 Bus. LAw 1, 10 (1983) (under Weinberger, "[e]xcept in cases of fraud . . . a showing of fair price without more will likely meet the majority's obligation . . . [and] appraisal should be considered a complete remedy"). To the contrary, the court may not have intended to limit "entire fairness" to "fair price." Weiss, Phase Six, supra note 1, at 258 ("shareholders who are able to demonstrate unfairness in other aspects of the transaction [than price] will continue to have the ability to maintain class actions").

21. See Weinberger v. UOP, Inc., 457 A.2d 701, 705 (Del. 1983) (parent's directors "purportedly" kept in mind that parent "owed a fiduciary responsibility to bath its own stockholders as well as to [the subsidiary's] minority"). For the gains that the parent hoped to realize for its own shareholders, see id. at 708 .

22. This impasse is illustrated by Tanzer v. International Gen. Indus., Inc., in which the Delaware Supreme Court confronted the issue "whether the parent may cause a merger to be made solely for its own benefit, or whether that is a violation of fiduciary duty." 379 A.2d at 1123 . The court attempted to uphold both of these alternatives. It held that "each stockholder represents himself and his own interests solely and in no sense acts as a trustee or representative of others." Id. at 1124 (quoting W. Fletcher, Cyclopedia of the Law of Private Corporations § 2031 (rev. perm. ed. 1980)). But the court added that the shareholder's right to vote in his own interest was limited "by any duty he owes to other stockholders," 379 A.2d at 1124, and remanded the case for judicial scrutiny of the "entire fairness" of the transaction. 


\section{B. Federal Law}

The disclosure requirements in federal securities regulations are more clearly defined than obligations of fiduciary duty in state corporation law. ${ }^{23} \mathrm{~A}$ sense of limited congressional purpose and limited jurisdiction permeates many federal court decisions under the securities laws and corroborates a more general sense of the limits of adjudication in the area of corporate law. ${ }^{24}$ In Mills v. Electric Auto-Lite, the Supreme Court held that courts should not place their own assessment of a merger's substantive fairness above an informed vote by the participants. ${ }^{25}$ The Court held: "There is no justification for presuming that the shareholders of every corporation are willing to accept any and every fair merger offer put before them. . . . [I]t is pure conjecture to assume that the fairness of the proposal will always be determinative of their vote."26 The ruling left substantive fairness to the determination of the parties and procedural fairness to the determination of the courts.

Nothing similar to Mills has appeared in state cases to qualify a virtually unanimous reliance on judicial determinations of substantive fairness. ${ }^{27}$ This neglect may stem from the fact that the Court in Mills had no basis for emphasizing the importance of free choice other than the supposed congressional purpose in enacting the Securities Exchange Act. ${ }^{28}$

Modern financial theory provides independent corroboration of the congressional policy by indicating that an aggregation of independent assess-

23. The most important disclosure requirements bearing on issues raised by take-out mergers are contained in the Securities Exchange Act of 1934, 15 U.S.C. $\S 78$ (1982), and rules promulgated thereunder, 17 C.F.R. $\S 240$ (1982). Rule 10b-5 forbids deceptive and manipulative practices in the purchase and sale of securities, 17 C.F.R. $\$ 240.10 \mathrm{~b}-5$; rules promulgated under Rule 14 concern disclosures required in proxy statements, C.F.R. \$ 240.14. Rule 13e-3, concerning going private transactions, requires the acquirer to state whether he reasonably believes that the transaction is fair or unfair to unaffiliated security holders. 17 C.F.R. $\$ 240.13 e-3$. This rule is the Securities and Exchange Commission's most overt attempt to enforce substantive fairness indirectly through the mechanisms of disclosure. Sep Note, Regulating Going Pritate Transactions: SEC Rule 13e-3, 80 Colum. L. REv. 782 (1980) (item 8 goes beyond congressional intent and intrudes into areas traditionally governed by state law).

24. This sense of limits is especially noteworthy in opinions of the Supreme Court construing Rule 10b-5 (forbidding deceptive and manipulative conduct in the purchase or sale of securities) more narrowly than urged by the Securities and Exchange Commission. See Santa Fe Indus. v. Green, 430 U.S. 462, 479 (1977) (complaint for fiduciary breach does not state a claim under Rule 10b-5 absent deceptive and manipulative conduct; to rule otherwise would be to federalize corporation law and override state policies); Ernst \& Ernst v. Hochfelder, 425 U.S. 185, 214 (1976) ("we are quite unwilling to extend the scope of the statute to negligent conduct"); Blue Chip Stamps v. Manor Drug Stores, 421 U.S. $723,739-40$ (1975) (rule granting standing to sue under Rule 10b-5 only to actual purchasers or sellers upheld in order to discourage "vexatious" litigation).

25. 396 U.S. 375 (1970).

26. Ill. at $382-83$ n.5.

27. Mills, if it had been considered at all, might have been distinguished as dealing with a stockfor-stock reorganization, instead of a cash-out. But such a distinction would be undermined by the fact that Sterling v. Mayflower Hotel Corp., 93 A.2d 107 (1952), the precedent upon which the Singer cases are overtly based, also involved a stock-for-stock reorganization.

28. 396 U.S. at 381 . 
ments of a proposed transaction's value will be more accurate than any single assessment, however expert. ${ }^{29}$ Share prices change in part because investors, initially in the minority, discover genuinely new information that becomes the basis for new prices. ${ }^{30}$ The take-out merger substitutes a single investment decision (the controlling shareholder's) for a series of uncoordinated decisions by numerous investors that in the aggregate would determine a more accurate price. Minority approval reestablishes a market-like aggregation of choices within a single transaction. Accurate information and the duty to disclose such information to minority shareholders become far more important when these shareholders have power to approve or reject the transaction than when the controlling shareholder has unilateral power to ratify its own prior decision.

\section{The Benefits of Minority Approval}

Minority approval helps in three ways to solve the nearly intractable legal problems posed by take-out mergers. First, it facilitates adjudication of disputed transactions by shifting the emphasis of judicial scrutiny from fair price to free choice. Second, it mitigates the coerciveness of take-outs, not only by protecting minority shareholders from ill-considered or exploitive terms, but also by protecting the controlling shareholder (and its shareholders) from meretricious legal actions. Finally, it encourages more adequate valuation of a transaction by all of the participants.

\section{A. Facilitating Adjudication}

By providing a credible demonstration of a take-out's fairness, minority approval should both reduce the number of groundless suits and make those transactions which are litigated more amenable to judicial scrutiny. While no court has accepted minority approval as establishing per se fairness and exempting the transaction from judicial scrutiny, it is well settled that approval by a majority of the minority shares does establish a rebuttable presumption that the transaction was fair ${ }^{31}$ Given the difficulty of

29. W. Beaver, Financial Reporting: An Accounting Revolution 159-60 (1981):

[P]rices act as an aggregation of everyone's information, such that the price "reflects" information that is superior to that held by each and every individual . . . . [I]diosyncratic behavior, by definition, is essentially uncorrelated among individuals. As a result, security prices, which can be viewed as a "consensus" across investors, are effectively able to diversify away the large idiosyncratic component . . . . By analogy, the individual investors' beliefs can be viewed as akin to individual securities and the security price can be viewed as an aggregate akin to a portfolio.

30. See R. Gilson \& R. Kraakman, The Mechanisms of Market Efficiency, Working Paper \# 13, Civil Liability Program, Yale Law School 24-25 (July 1983) (new information, even if trivial or fragmented in itself, can have value by altering existing information upon which forecasts are based).

31. Weinberger v. UOP, Inc., 457 A.2d 701, 703 (1983) ("where corporate action has been approved by an informed vote of a majority of the minority shareholders . . . burden entirely shifts to 
sustaining the burden of proof in the economic dimensions of a corporate reorganization,,$^{32}$ the effect of the presumption is to shift the gravamen of complaints from the intrinsic fairness of the price to the adequacy of the disclosures made to minority shareholders. ${ }^{33}$ This development makes adjudication of disputed take-outs easier and more certain. Intrinsic value-if it exists at all-is difficult to measure. By contrast, disclosure is readily documented and verified. Moreover, the requirements of disclosure and free choice are intuitively obvious: Shareholders must have all information that a reasonably prudent investor would consider significant in deciding how to vote.

Federal courts have held that information is material in securities regulation "if there is a substantial likelihood that a reasonable shareholder would consider it important in deciding how to vote."34 Nondisclosure of material information is an offense in itself; a plaintiff need not prove that shareholders were actually misled, or that the merger would not have been approved had the defendant disclosed the information. ${ }^{35}$

The rationale of this rule, however, is eroded in the case of a take-out merger where the controlling shareholder has sufficient votes to carry the transaction unilaterally. In such a case, a reasonable minority shareholder, knowing that his vote can make no difference, might not consider any information important in deciding which way to vote, and would probably not vote at all. ${ }^{36} \mathrm{~A}$ federal court, assessing the materiality of an alleged nondisclosure, would have to hypothesize the response of a reasonable

the plaintiff to show that the transaction was unfair to the minority").

32. See supra pp. 1114-15.

33. See Weinberger v. UOP, Inc., 457 A.2d 701, 703 ("burden clearly remains on those relying on the vote to show that they completely disclosed all material facts relevant to the transaction"); $c f$. Harman v. Masoneilan Int'l, Inc., 442 A.2d 487, 492 (Del. 1982) (minority shareholders' approval of the merger does not justify dismissal when plaintiff alleges that "public shareholders' approving votes were 'coerced' through a materially false and misleading proxy statement"). If Weinberger is construed as eliminating Singer's requirement of "entire fairness" (in addition to the "business purpose" requirement) and relegating dissident shareholders (except those alleging outright fraud) to an appraisal hearing, then controlling shareholders may eschew minority approval in order to limit the scope of disclosure. See generally Berger \& Allingham, supra note 20, at 23 ("Where the minority is given the right to block the merger ... the disclosures germane to the minority would appear to include virtually all aspects of the corporation's operations, management, future plans, and prospects as opposed to the more limited facts relating to value which would be material if the stockholders were not empowered to prevent the merger, but had only fair-value rights."). It is questionable, however, whether a court could distinguish "facts relating to value" from other "aspects of the corporation's operations, management future plans, and prospects"; the court in Weinberger suggests that all such information is "relevant" to an appraisal proceeding. $457 \mathrm{A.2d}$ at 713. Moreover, the court in Weinberger expressly disavowed any intention to limit dissenting shareholders' equitable remedies.

34. TSC Indus., Inc. v. Northway, Inc., 426 U.S. 438, 449 (1976).

35. Affiliated Ute Citizens of Utah v. United States, 406 U.S. 128, 152-54 (1972).

36. See R. Jennings \& H. Marsh, Securities Regulation 1027 (5th ed. 1982) (Materiality "can only be given content by considering the question in the context of all the circumstances of the transaction .... If the [plaintiff] has no choice in the matter, then no information is 'material' to him."). 
shareholder whose vote could make a difference. By measuring materiality, the hypothetical vote has dispositive legal consequences, even though the actual votes are immaterial. Courts have upheld this anomalous result to preserve the indirect benefits of disclosure: informing the market about the merger, inhibiting otherwise rapacious controlling shareholders, and encouraging "private attorneys general" to seek enforcement of the securities laws. ${ }^{37}$

Minority approval would bring the federal courts' hypothetically reasonable investor to life and give "material" information an actual role to play in the outcome of proposed take-out mergers. It would encourage otherwise indifferent minority shareholders to make research investments that (when aggregated by their vote) bring new information to the market. And it would allow both federal and state courts, over time, to discover concretely and in detail what information actually is material to shareholders in a position to use it.

\section{B. Mitigating Coercion}

Take-out mergers are less coercive when the controlling shareholder allows the minority shareholders to decide as a group whether the transaction should be completed or not. Of course, even with minority approval some coerciveness remains, since the controlling shareholder retains its ability to set the proposed terms at a time of its own choosing and to oblige the minority to make a decision. ${ }^{38}$ Moreover, unless the vote is unanimous, some shareholders will be forced to accept a transaction not to their liking. But this coercion could be eliminated only at the cost of granting each shareholder a veto, which ultimately would be even more coercive.

The power of minority approval to mitigate coercion is best illustrated by the response it allows to holdouts who will not accept any price for their shares. Under minority approval, the coercion necessary to remove holdouts will be exercised only by other minority shareholders who occupy the same position as the holdouts and who are willing to accept the

37. See Schlick v. Penn-Dixie Cement Corp., 507 F.2d 374, 378 n.7, 383-84 (2d Cir. 1974) (disclosure informs the market and restrains controlling shareholder; $\$ 14(c)$ of 1934 Act requires disclosure even for shareholder actions not solicited by proxies); Rosenblatt v. Northwest Airlines, Inc., 435 F.2d 1121, 1124 (2d Cir. 1970) (shareholder functions as a private attorney general to assist the SEC in enforcing $\$ 14(\mathrm{a}))$.

38. Weinberger v. UOP, Inc., 409 A.2d 1262, 1265 (Del. Ch. 1979), rez'd on other grounds, 457 A.2d 701 (Del. 1983) ("whenever a majority shareholder . . u undertakes to exercise an available statutory power so as to impose the will of the majority upon the minority, such action gives rise to a fiduciary duty on the part of the majority shareholder to deal fairly with the minority whose property interests are thus controlled"); see Brudney \& Chirelstein, supra note 2, at 307. 
offered terms, not by the controlling shareholder who proposes the terms and who seeks to gain sole possession of the enterprise.

As minorities become smaller and more vulnerable, their power under the proposed voting procedure would grow proportionately. The question then arises whether majorities would be exploited by very small minorities which could extort a high price for approval. This danger would be especially great in cases where a holder of the majority of the minority shares is a former competitor for control in a tender offer-the result of a "twostep" transaction. The first step is a tender offer; the second, a take-out merger. Where the terms of the take-out are disclosed in the initial tender offer, however, there is but one transaction for which the tender of shares operates as a vote by holders not affiliated with the would-be acquirer..$^{39}$ Hence a second minority vote to approve the take-out would be inappropriate in this special case. ${ }^{40}$

Parent-subsidiary and "going-private" transactions are distinguishable from two-step mergers. While minority approval would allow a small number of shareholders to block all three types of merger, the majority in parent-subsidiary and going-private mergers is generally better able to accommodate the minority by offering alternative consideration (e.g., stock for stock) or by making repeated offers over time.

Moreover, in parent-subsidiary and "going-private" transactions, minorities typically become small through "creeping acquisitions" by the majority. This strategy, often condemned as evasive because it eludes regulation and judicial scrutiny, ${ }^{41}$ would be discouraged by a minority-approval voting procedure, because the risk of a negative vote would increase as the minority grew smaller, less representative, and more unpredictable. A prompt and forthright offer to a relatively large minority would then be the preferable course-from the strategic as well as the equitable point of view. In an extreme case, the majority would be required either to forgo the transaction or to complete it without minority approval-and bear the burden of proof if a minority shareholder sues. But in an extreme case, the burden of proof would not be hard to bear.

39. Such two-step tender offers are construed as single transactions under Rule $13 e-3$, Securities Exchange Act of 1934. See Brudney \& Chirelstein, supra note 2, at 330-40.

40. Unfavorable consequences of requiring minority approval of the second step in a two-step tender offer are analyzed by Gilson, The Case Against Shark Repellent Amendments: Structural Limilations on the Enabling Concept, 34 STAN. L. REv. 775, 784-85 n.41 (1982) (supermajority charter provisions prompt offerors to acquire fewer shares in the first-round tender offer, leaving a larger number of shareholders favoring the transaction "frozen in" until the second-round take-out can be completed).

41. See Tobin \& Maiwurm, Beachhead Acquisitions: Creating Waves in the Marketplace and Uncertainty in the Regulatory Framework, 38 Bus. LAw. 419 (1983); Atkins, Defense Against Creeping Acquisitions, in ThIRTEenth Annual InStItUTe on Securities Regulation 57 (1982). 


\section{G. Improving Valuation}

Minority approval would motivate minority shareholders to estimate the value of the transaction because they would have power to determine the outcome. Without minority approval, the controlling shareholder can impose any price, so long as it is high enough to discourage minority shareholders from exercising their statutory appraisal rights or bringing suit for breach of fiduciary duty. But where the minority has power over the transaction, the controlling shareholder must estimate what price a reasonable shareholder will accept. The minority may then be prompted to make an intelligent evaluation instead of responding with the apathetic acquiescence that often characterizes shareholder ratification. ${ }^{42}$ The minority shareholders face an important choice: to accept the offer and reinvest the cash in other ventures, or to reject it in hopes either that a higher offer will be forthcoming or that the retained shares will increase in value.

The controlling shareholder can be reasonably certain of acceptance only by offering a premium that exceeds not only the pre-merger market price of the shares but also the estimated value of the future prospects-a higher cash-out offer or continued participation-that the minority could keep open by voting against the cash-out price. To succeed, therefore, the controlling shareholder must distribute to the minority an amount at least equal to its collective estimate of the future value of all potentially available alternatives. Minority approval thus provides an equitable means to distribute the anticipated gains from the transaction between the controlling and minority shareholders.

Courts and commentators have urged the appointment of independent directors to bargain for the minority shareholders. ${ }^{43}$ Formal negotiations between a majority shareholder and independent directors would increase

42. Brudney and Chirelstein forcefully argue that ex post shareholder ratification has little significance in demonstrating the fairness of a transaction, although they concede that "[v]oting rights do serve, however, as a conceptual premise on which to build a requirement of disclosure." Brudney \& Chirelstein, supra note 2, at 300 . In terms of financial theory, "apathetic" shareholders might be regarded as taking a free ride on the research expenditures made by those whose actions they uncritically endorse. Since securities are fungible, the value of a security in a portfolio depends most of all on the lack of correlation of its expected returns with the expected returns of other securities in the portfolio. Sep R. Brealey \& S. Myers, Principles of Corporate Finance, 122-29 (1981); J. Van Horne, Financial Management and Policy 46-50 (6th ed. 1983). A shareholder holding a diversified portfolio of stocks has good reason to accept any premium over market and reinvest the proceeds in some other security. See Easterbrook \& Fischel, Voting in Corporate Law, 26 J.L. \& ECON. 395, 420 (1983) ("Because of the easy availability of the exit option through the stock market, the rational strategy for dissatisfied shareholders in most cases . . . is to disinvest rather than incur costs in attempting to bring about changes through the voting process.").

43. Sep Chazen, supra note 6 , at 1449-50, 1466-77 (recommending use of independent negotiators). The court in Weinberger has made the use of independent negotiators a virtual prerequisite: "Since fairness in this context can be equated to conduct by a theoretical, wholly independent, board of directors acting upon the matter before them it is unfortunate that this course apparently was neither considered nor pursued." 457 A.2d at 709 n.7 (citations omitted). 
the likelihood that the transaction would be well considered. ${ }^{44}$ But negotiation will not necessarily result in a higher price than the controlling shareholder would unilaterally offer to dispersed and disorganized minority shareholders. ${ }^{45}$ The give-and-take of arm's-length bargaining will produce an average or compromise price that might well be lower than the marginal price needed to bring in a majority of the minority shares when each shareholder votes independently. ${ }^{46}$ If minority approval is required in addition to negotiation, the negotiated price will be higher whenever a compromise price appears too low to bring in the last necessary share. Thus, minority approval and negotiation together are more effective in ensuring a fair and valid result than either alone. ${ }^{47}$

The minority's vote is important not merely as a concession to shareholders' rights of ownership and participation, but also as a means to establish value under uncertainty in the marketplace. If the minority's approval is not sought, or if it is invalidated by a subsequent finding of fraud or misrepresentation, the court will need to determine whether the

44. The contrary impression of haste, carelessness, and mere neglect of minority interests has been fatal to disputed transactions. Most recently, the court in Weinberger v. UOP, Inc., $457 \mathrm{~A} .2 \mathrm{~d}$ at 712 , found that the defendant had rushed the merger and failed to give its terms careful consideration.

45. Chazen points out that a controlling shareholder in arm's-length negotiations will generally pay a lower price per share for the company's publicly-held shares than an outside buyer would pay for the entire company, because the outsider would have to pay a control premium. Chazen, supra note 6 , at 1468 . When a merger requires minority approval, the minority has a degree of control, and therefore may command a higher price than would be paid to a minority lacking control. This premium is an adequate proxy for the minority's rightful share of the gains expected from the merger.

46. The price demanded by the last shareholder necessary to assemble a majority of the minority must be paid to all of the shareholders who would have accepted a lower price as well as to those who would have held out for a higher price. The average price will be lower than the marginal price if the holdouts (who are usually individual investors) have fewer shares than other shareholders who are willing to accept any price that would make them marginally better off. (This result is likely if a large number of the shares are held by institutional investors with large, diversified portfolios, whose transaction costs are relatively low; such investors are the most likely to accept a low cash premium over market and reinvest in other securities.) In this respect, minority approval of a take-out would resemble a successful tender offer:

The tender offer's success will depend on the demand of the last necessary shareholder. The

higher cost of tender offers should reflect the tendency for individual shareholders bargaining

separately to demand more in the aggregate than an objective appraisal of the value of the corporation would justify ... [or than] might be determined in arm's-length negotiations.

Toms, supra note 13, at 557-58 (footnotes omitted).

47. If arm's-length negotiation is employed as an alternative to minority approval, the result might be to relax the disclosure requirement and thus permit a divergence of state from federal standards of fairness. The Weinberger opinion can be read to imply that a controlling shareholder who negotiates at arm's length with independent representatives of the minority shareholders no longer has fiduciary duties to them and need not disclose his assessment of the transaction's value. 457 A.2d at 710-11 ("individuals who act in a dual capacity as directors of two corporations, one of whom is parent and the other subsidiary, owe the same duty of good management to both corporations, and in the absence of an independent negotiating structure. . . this duty is to be exercised in light of what is best for both companies"; the duty includes the requirement of "complete candor") (emphasis added). The court condemned the defendant in Weinberger for failing to disclose to the minority an internal memorandum, prepared by two dual directors for the sole use of defendant, which indicated that the defendant had been willing to pay four dollars per share more than it offered to the minority. Information about a party's reservation price is usually concealed in arm's-length bargaining. 
price paid was a fair distribution of the value of the transaction. Ex ante, that distribution can be determined only by a shareholder vote (an aggregation of estimates); ex post, it can be determined only by a judicial approximation of the terms that reasonable shareholders in similar circumstances would have voted to accept, if given the chance. It is easier and more equitable to give them the chance than to estimate after the fact what they would have done with it.

\section{CoNCLUSION}

"Fairness," judicially determined after the fact, is no substitute for a free choice by the affected parties. The majority shareholder provides such a choice when it submits a proposed take-out merger to a vote by the minority shares whose removal it seeks. In this case, the price is indeed an amount taken-if it is taken-in exchange, not compensation unilaterally paid for a coercive exclusion.

Minority approval protects minority shareholders from unfair dealing, thereby complementing the protection offered by state appraisal statutes and by legal or equitable actions for fraud or breach of fiduciary duty. It also protects the controlling shareholder, as well as its shareholders, by shifting the burden of proving unfairness to the dissidents. It further protects both sides by encouraging them to consider the terms of the transaction more carefully than is necessary when the terms are unilaterally imposed.

Minority approval also facilitates adjudication by shifting its emphasis to the issue of disclosure; courts can more readily assess the adequacy of disclosure than the substantive fairness of the price. By emphasizing disclosure, minority approval brings substantive state corporation law governing the fairness of take-out mergers into closer harmony with federal law governing the sale and exchange of corporate securities, a central purpose of which is to require disclosure, as a means of protecting free and informed choice. Thus a disputed transaction effected by a vote of the minority shares permits a state or federal court of equity to employ the concepts and insights of securities regulation in adjudicating disputed take-out mergers. 